Др Борис Тучић,

Доцент,

Факултет безбједоносних наука,

Универзитет у Бањој Луци
ПРЕГЛЕДНИ НАУЧНИ РАД

$10.5937 /$ zrpfn0-33261

UDK: 327:061.1 EU

Рад примљен: 22.07.2021.

Рад прихваћен: 10.09.2021.

Апстракт: Применом аналитичких и синтетичких метода, попут анализе садржаја и компаративне анализе, у раду се разматра деловање судова Уније по питању примене аутономних рестриктивних мера против правних и физичких лица и недржавних ентитета у оквиру ЗСБП. У раду се анализира уговорни и институционални контекст ове врсте рестриктивних мера, сагледава уговорна позищија Суда правде у оквиру ЗСБП, те разматрају најрелевантнији аспекти судске праксе по овом питању, а посебно настојање Суда да ојача властити капацитет у области ЗСБП, јуриспрудентна идентификација процесних критеријума које одлуке о рестриктивним мерама морају испунити, као и напори судова Уније у правцу заштите људских права и слобода при примени рестриктивних мера, укључујући и право на накнаду штете. На крају су дата закључна разматрања аутора у којима се, између осталог, констатује да је досадашња судска пракса, уз јачање позиције Суда правде у оквиру ЗСБП, примарно посвећена обезбеђењу својеврсне равнотеже између ефикасности и ефективности инструмената ЗСБП, с једне стране, те заштите базичних вредности на којима правни поредак Уније почива, с друге, међу којима се посебно издвајају владавина права, правна сигурност, ефикасна судска заштита, односно заштита људских права и слобода како их гарантује право Уније.

Кључне речи: ЗСБП, аутономне рестриктивне мере, судска пракса, правна и физичка лица и недржавни ентитети, Суд правде ЕУ, Општи суд, процесни критеријуми, људска права.

*boris.tucic@predsjednikrs.net 


\section{1. Увод: уговорни и институционални контекст аутономних рестриктивних мера}

Битан облик принудног деловања Европске уније (ЕУ) у постлисабонском периоду, како у борби против тероризма, тако и у реализацији њених циљева у оквиру Заједничке спољне и безбедносне политике (ЗСБП), јесу аутономне рестриктивне мере против правних и физичких лица и других недржавних ентитета ${ }^{1}$. За разлику од екстерних мера, попут оних које утврђује Савет безбедности ОУН, аутономне рестриктивне мере ЕУ оригинално креирају и усвајају њене институције, укључујући и релативно самосталну идентификацију индивидуалних субјеката чија се права оваквим мерама редукују или суспендују.

Експлицитна уговорна основа за доношење рестриктивних мера против ове категорије лица предвиђена је тек Уговором из Лисабона, иако је Унија и раније усвајала одређене мере које нису биле усмерене само против трећих држава, како је то уговорно изричито било омогућено, већ и против њиховог руководства. По члану 301 Уговора о Европској заједници (УЕ3), примена економских санкција против трећих држава захтевала је претходно доношење одговарајућег акта ${ }^{2}$ у оквиру ЗСБП од стране Савета, док је чланом 60.1 истог уговора била предвиђена и спецификована основа за доношење хитних мера везаних за кретање капитала и плаћања у односу на земље које су предмет мера донетих на основу члана 301. Тиме, режим примене санкција у предлисабонском периоду био је двофазног карактера и подразумевао је доношење одговарајућег акта у оквиру ЗСБП те, зависно од природе санкција и надлежности за њихово провођење, усвајање имплементационих мера од стране институција организације и држава чланица. Но, на основу његовог екстензивног тумачења, које је подржао и Суд правде, Савет је члан 301 УЕ3 користио и за доношење мера усмерених не само против трећих држава ${ }^{3}$, већ и против конкретних

1 Ова врста рестриктивних мера се у теорији означава и као „циљане“ или „паметне“ санкције.

2 У форми заједничког става, односно заједничке акције.

3 Видети: Common Position of 19 March 1998 on restrictive measures against the Federal Republic of Yugoslavia, OJ 1998 L 95/1 и Common Position of 7 May 1998 concerning the freezing of funds held abroad by the Federal Republic of Yugoslavia (FRY) and Serbian Governments, OJ 1998 L 143/1. 
правних и физичких лица4 ${ }^{4}$ Случај Minin $^{5}$, на пример, указује да је доношење оваквих мера на основу члана 301 УЕЗ могуће услед територијалне и институционалне повезаности лица са државом која је предмет санкција, док је у случају Kadi истакнуто да санкције против државе могу обухватити и њено руководство, односно појединце и ентитете који се с њим доводе у везу или су под његовом контролом ${ }^{6}$. Случај Melli ${ }^{7}$ указао је да предмет санкција могу бити и банке у недржавном власништву, уколико финансијски подржавају развој нуклеарног програма земље супротно нормама међународног права. Временом, ипак, појављивали су се одређени проблеми са оваквим начином (зло)употребе члана 301 УЕЗ. Тако, падом талибанског режима у Авганистану 2002. године, уговорна формулација „економске санкције против трећих држава“ као основа за доношење мера и против недржавних субјеката постала је додатно спорна, јер се припадници Ал Каиде више нису могли довести у везу са „руководством треће државе“. Такође, појавило се и питање основе за доношење рестриктивних мера против „домаћих терориста“, односно грађана Уније пореклом са Блиског и Средњег истока. Да би превазишао наведене изазове и омогућио флексибилнију основу за деловање Уније, Савет се настојао ослањати и на члан $308^{8}$ УЕ3, те функционално га повезујући са члановима 301 и 60.1 покушавао идентификовати додатне, комплементарне надлежности организације у овом контексту. Ипак, како jе показао и случај Kadi, у којем су тадашњи Првостепени суд, Суд правде и општи правобранилац изнели различите ставове по кључним процесним питањима, овакво деловање Савета стварало је само додатну конфузију (Van Elsuwege, 2011: 490-493).

Лисабонски уговор поједноставио је ситуацију, предвиђајући две експлицитне и самосталне правне основе за доношење овакве врсте мера, једну у члану 75, а другу у члану 215.2 Уговора о функционисању

4 Видети: Council Regulation (ЕC) No 2488/2000 of 10 November 2000 maintaining a freeze of funds in relation to Mr. Milosevic and those persons associated with him and repealing Regulations (EC) No. 1294/1999 and 607/2000 and Article 2 of Regulation (EC) No 926/98, OJ 2000 L 287/19.

5 Case T-362/04, Leonid Minin v. Commission, 2007, ECR II-2003.

6 Joint Cases C-402/05 P and C-415/05 P, Kadi and Al Barakaat, 2008, ECR I-6351, para. 67.

7 Joined Cases T-246/08 and T-332/08, Melli Bank plc v. Council, [2009] ECR II-2629, para. 69.

8 Члан 308 УЕЗ омогућавао је Савету да, уколико Уговор није предвиђао конкретно овлаштење за спровођење неопходних активности Заједнице у области функционисања унутрашњег тржишта, као једног од циљева оснивачког акта, ипак предузме одговарајуће мере, на основу предлога Комисије и након консултовања Парламента. Данас је реч о значајно измењеном и допуњеном члану 352 УФЕУ. 
Европске уније (УФЕУ)․ Самосталност ових правних основа огледа се како у прекидању процесноправне међузависности каква је постојала између чланова 301 и 60.1 УЕЗ, тако и у њиховим засебним циљевима и функцији у правном систему организације. Члан 75 омогућава доношење рестриктивних мера у оквиру „Простора слободе, безбедности и правде“" ${ }^{\prime \prime}$, посебно у контексту борбе против тероризма и повезаних активности и њим је, између осталог, отклоњен проблем адресирања „домаћих терориста“ из предлисабонског периода. С друге стране, члан 215.2 Уговора ${ }^{11}$ омогућава имплементацију одлука у оквиру ЗСБП којима се редукују или суспендују економски односи са трећим државама, али и, у складу са његовим другим параграфом, доношење санкционих мера против правних и физичких лица, група и недржавних ентитета. Наведеним члановима предвиђена је и примена различитих поступака, јер члан 215.2 УФЕУ подразумева претходно једногласно донету одлуку у оквиру ЗСБП, на основу које Савет, квалификованом већином и на предлог Високог представника за спољну политику и безбедност и Комисије, те уз информисање Парламента, доноси меру, док члан 75 реферише само на редовни поступак из члана 294 УФЕУ. Временом, мере на основу члана 215.2 УФЕУ преузеле су примат (Pursiainen, 2017). Пратећи „кризна жаришта“ у свету, од Блиског и Средњег истога до Украјине и Руске Федерације, Унија је до сада у оквиру ЗСБП имплементирала преко тридесет различитих модалитета рестриктивних мера против правних и физичких лица и других недржавних субјеката за које је оцењено да представљају опасност по њене циљеве и вредности (Challet, 2020).

Иако је донео одређена побољшања, Уговор из Лисабона није отклонио све недоумице, поготово у контексту идентификације уговорне основе, а тиме и улоге, статуса и овлаштења појединих органа у поступку доношења рестриктивних мера, о чему сведочи и познати спор између Парламента и Савета по питању измена и допуна регулативе 881/2002/EC којом се предвиђају мере против индивидуалних субјеката повезаних за Бин Ладеном, Талибанима и Ал Каидом ${ }^{12}$. Комисија је сматрала да је уговорна

9 Измењени и допуњени чланови 60 и 301 некадашњег УЕЗ.

10 Уговором из Амстердама као један од циљева предвиђено је успостављање Простора слободе, безбедности и правде у оквиру Уније. Реч је о генеричком називу за области политика у домену унутрашњих послова и правосуђа. Погледати: Тучић, Б. (2020). Основи политике интеграције и сарадње у области унутрашњих послова и правосуђа у Европској унији: правни и институционални оквир „Простора слободе, безбједности и правде“. Бања Лука: Факултет безбедносних наука.

11 Глава VI Дела V Уговора посвећеног спољним активностима Уније.

12 Council Regulation (EC) No 881/2002 of 27 May 2002 imposing certain specific restrictive measures directed against certain persons and entities associated with Usama bin Laden, 
основа за наведене измене и допуне садржана у члану 215.2 УФЕУ, што је подразумевало и значајно редукованију улогу Парламента у поступку, док је Парламент сматрао да то може искључиво бити члан 75 УФЕУ, јер је сврха предметних мера управо борба против тероризма ${ }^{13}$. Међутим, након што је регулатива $1286 / 2009^{14}$, којом су извршене измене и допуне регулативе 881/2002/ЕС, донета на основу члана 215.2 УФЕУ, Парламент је покренуо поступак пред Судом правде, захтевајући поништење акта Савета из процесних разлога, међу које су, уз погрешну уговорну основу, спадали и неиспуњавање процесних критерија из члана 215.2 УФЕУ у смислу обезбеђења заједничког предлога акта од стране Високог представника и Комисије, односно неадекватност заједничког става 2002/42 ${ }^{15}$ Савета као основе за доношење регулативе ${ }^{16}$. Но, Суд правде је одбацио аргументе Парламента и стао на страну Савета и Комисије ${ }^{17}$.

\section{2. Суд правде и аутономне рестриктивне мере у области ЗСБП}

\section{1. Уговорна надлежност Суда правде у оквиру ЗСБП}

Уз експлицитну надлежност за доношење рестриктивних мера против индивидуалних субјеката, лисабонски Уговор предвидео је и прилично ограничену надлежност Суда правде у оквиру ЗСБП. По члану 24.1 УЕУ Суд је надлежан да надзире стриктно поштивање члана 40 истог уговора којим је, у суштини, дефинисан однос ЗСБП према осталим областима спољњег деловања Уније, а тиме и осталим областима њеног деловања

the Al-Qaida network and the Taliban, and repealing Council Regulation (EC) No 467/2001 prohibiting the export of certain goods and services to Afghanistan, strengthening the flight ban and extending the freeze of funds and other financial resources in respect of the Taliban of Afghanistan, OJ L 139, 29. 5. 2002, p. 9-22.

13 European Parliament Committee on Legal Affairs, Opinion on the legal basis of the proposal for a Council Regulation amending Regulation (EC) No 881/2002 imposing certain specific restrictive measures directed against certain persons and entities associated with Osama bin Laden, the Al-Qaida network and the Taliban, JURI_AL(2009) 430917, 4 December 2009, p. 8. 14 Council Regulation (EU) No 1286/2009 of 22 December 2009 amending Regulation (EC) No 881/2002 imposing certain specific restrictive measures directed against certain persons and entities associated with Osama bin Laden, the Al-Qaida network and the Taliban, O.J. 2009, L 346/42.

15 Council Common Position of 27 May 2002 concerning restrictive measures against Usama bin Laden, members of the Al-Qaida organisation and the Taliban and other individuals, groups, undertakings and entities associated with them and repealing Common Positions 96/746/ CFSP, 1999/727/CFSP, 2001/154/CFSP and 2001/771/CFSP, OJ L 139, 29. 5. 2002, p. 4-5.

16 Case C - 130/10, European Parliament v. Council, ECLI:EU:C:2012:472.

17 Погледати посебно: ibidem, para. 100-112. 
уопште (Тучић, 2015: 73). Друга, за нас значајнија надлежност Суда у оквиру ЗСБП садржана је у члановима 24.1 УЕУ и 275.2 УФЕУ, а односи се на оцену законитости ${ }^{18}$ управо аката Савета којима се уводе рестриктивне мере против правних и физичких лица на основу уговорних одредби у области ЗСБП. Очито, како указују наведена уговорна решења ${ }^{19}$, лисабонска регулаторна асиметричност између ЗСБП и осталих области политика $\mathrm{У}_{\text {није }}{ }^{20}$ условила је и минималну надлежност Суда правде у области ЗСБП (Bartolini, 2021: 1360), са којом се Суд, као што ће се видети, није мирио.

Наиме, Суд правде је од старта настојао широко тумачити властиту позицију у оквиру ЗСБП, посматрајући уговорна решења из чланова 40 УЕУ и 275 УФЕУ из „перспективе огледала“. У случајевима ЕP vs. Council (Mauritius) ${ }^{21}$, Elitaliana $^{22}$ и $\mathrm{H}^{23}$, на пример, Суд је полазио од своје опште надлежности из члана 19 УЕУ, док је решења из чланова 40 УЕУ и 275 УФЕУ третирао само као њену својеврсну дерогацију. Или, како је истакао у случају Mauritius, „последња реченица из члана 24.1 УЕУ и први параграф члана 275 УФЕУ уводе дерогацију у односу на правило опште надлежности која је Суду додељена чланом 19 Уговора како би се обезбедило да се приликом интерпретације и примене уговора̄ поштује право те стога њихово значење мора бити тумачено веома уско“24. На основу става о дерогацији његове опште надлежности у оквиру ЗСБП, Суд је учинио следећи корак у правцу јачања своје позиције, а то је да овлаштење за оцену законитости мера из члана 215.2 УФЕУ не ограничи само на поступак за поништај из члана 263.4 , већ да га прошири и на утврђивање валидности аката у оквиру претходног поступка из члана 267 УФЕУ.У случају Rosneft ${ }^{25}$, Суд је овакво резоновање темељио на неспојивости ужег тумачења одредби члана 275 са сврхом претходног поступка, а то је опште поштивање права организације при тумачењу и примени уговорних одредби, природи надлежности којом Суд располаже по члану 19 УЕУ, те праву на ефикасну судску заштиту из члана 47 Повеље ЕУ о основним правима. По мишљењу Суда, неспојиво је са

18 У складу са чланом 263 Уговора о функционисању Европске уније.

19 Ова група уговорних одредби у теорији се означава као клаузула о постепеном повратку (енг. claw back clause).

20 Мисли се на чињеницу да је ЗСБП и Уговором из Лисабона позиционирана на међувладиним механизмима сарадње, за разлику од осталих области политика које почивају на тзв. интегративном регулаторном моделу.

21 Case C-658/11, EP v Council (Mauritius), ECLI:EU:C:2014:2025.

22 Case C-439/13P, Elitaliana, ECLI:EU:C:2015:753.

23 Case C-455/14P H v Council, ECLI:EU:C:2016:569.

24 Case C-658/11, EP v Council (Mauritius), ECLI:EU:C:2014:2025, para. 70.

25 Case C-72/15, PJSC Rosneft Oil Company v. Her Majesty's Treasury, ECLI:EU:C:2017:236. 
начелом ефикасне судске заштите уколико би се одредбе члана 275.2 УФЕУ тумачиле на начин да се њима национални судови онемогућавају да се обрате Суду у претходном поступку са питањем валидности аката Савета којима се уводе рестриктивне мере против индивидуалних субјеката, посебно знајући да су коначне импликације поступака из члана 263.4 и члана 267 УФЕУ идентичне ${ }^{26}$. Тиме је Суд поручио да ЗСБП, и поред регулаторне специфичности предвиђене чланом 24.1 УЕУ, чини интегралну компоненту права Уније, те да ће он приликом утврђивања законитости одлука Савета о рестриктивним мерама примењивати правна правила, принципе и начела која су важећа у осталим областима права организације. Такође, уколико одлуке о рестриктивним мерама подлежу утврђивању валидности у оквиру претходног поступка, оне несумњиво подлежу и интерпретативној надлежности Суда у складу са чланом 267 УФЕУ, о чему се у случају Rosneft изјаснио и општи правобранилац Вателет ${ }^{27}$.

\section{2. Процесни критерији и рестриктивне мере}

Битан сегмент деловања Суда правде односи се на идентификацију процесних критеријума које одлуке Савета о рестриктивним мерама морају испунити. Још од случаја Kadi II, Суд је истицао да примена рестриктивних мера против правних и физичких лица мора подлегати „пуној правосудној контроли“ у смислу поштивања људских права у оквиру правног поретка оганизације ${ }^{28}$. Но, поштујући уговорне прерогативе Савета у оквиру ЗСБП, судови Уније су „пуну контролу“ о којој је реч углавном сводили на процесну раван, не залазећи у материјалноправна питања. Након Лисабона, у судској пракси искристалисала су се три процесна критеријума на којима су судови инсистирали. Први је критеријум дезигнације, који подразумева индивидуализованост, прецизност и конкретност одлуке Савета, као и постојање везе између примене рестриктивних мера и остварења или заштите циљева Уније. Како указује случај Anbouba, Савет мора прецизно указати зашто је одређено лице предмет рестриктивних мера, као и да назначи повезаност њихове примене са остварењем циљева организације ${ }^{29}$. Судови Уније поштовали су дискрециона права Савета при идентификацији „мете“ рестриктивних мера, те деловали само у случају непоштивања захтеваних процесних критеријума, односно угрожавања начела правне

26 ibidem, paras. 60-71.

27 Case C-72/15, Rosneft, Opinion of Advocate General Wathelet delivered on 31 May 2016, ECLI:EU:C:2016:381, para. 75.

28 Joined Cases C-584/10 P, C-593/10 P \& C-595/10 P, Commission v. Kadi (Kadi II), EU:C:2013:518, para. 97.

29 Case C-630/13, Issam Anbouba v Council, ECLI:EU:C:2015:247, para 42. 
сигурности или принципа пропорционалности, како показују и основни и апелациони поступак у случају National Iranian Oil Company ${ }^{30}$. Други критеријум захтева израду, у форми анекса одлуке, детаљног образложења примене рестриктивних мера према конкретном лицу од стране Савета. Случајеви OMPI ${ }^{31}$, Kadi II ${ }^{32}$, Bamba ${ }^{33}$, Bank Saderat Iran ${ }^{34}$, Stavytskyi ${ }^{35}$ или Kargaran $^{36}$, показују да Савет мора јасно образложити зашто је одређено лице предмет рестриктивних мера, на начин који је разумљив и лицу у питању и судовима: лицу у питању како би могло судски заштити своја права и евентуално кориговати своје спорно понашање, а судовима како би могли вршити своју функцију контроле законитости ове врсте аката Савета. Или, како је Општи суд истакао у једном од случајева Yanukovych, образложење не може садржавати уопштене, стереотипне формулације, већ конкретне разлоге зашто Савет сматра да је такав акт примењив у односу на лице у питању ${ }^{37}$. Трећи критеријум захтева „поткрепљујуће доказе“ којима ће одлука о рестриктивним мерама, укључујући и детаљно образложење, бити подржана. Суд је остао недоречен по питању нивоа доказа у овом контексту, истакавши у случају Fulmen ${ }^{38}$ да се мора радити о доказима на основу којих се може објективно утврдити да је одлука

30 Поступак пред Општим судом: Case T-578/12, National Iranian Oil Company v Council, ECLI:EU:T:2014:678; апелациони поступак пред Судом правде: Case C-440/14, National Iranian Oil Company v Council, EU: C:2016:128. Погледати и случај T-348/14, Yanukovych v Council, ECLI:EU:T:2016:508, у којем је Општи суд поништио одлуку Савета јер није адекватно утврђена повезница између наводне злоупотребе јавних финансија и нарушавања владавине права и инстиуционалне стабилности у Украјини, односно случај C - 348/12 P Council of the European Union v Manufacturing Support \& Procurement Kala Naft Co., Tehran, ECLI:EU:C:2013:776, који се тицао идентификације лица као објекта рестриктивних мера не на основу његовог претходног или постојећег, већ на основу његовог будућег „ризичног“ деловања по спољнополитичке интересе и циљеве Уније ("risk designation criteria").

31 Case T-228/02, Organisation des Modjahedines du peuple d'Iran v. Council, ECLI:EU:T:2006:38.

32 Joined Cases C-584/10 P, C-593/10 P \& C-595/10 P, Commission v. Kadi (Kadi II), EU:C:2013:518.

33 Case C-417/11, Council of the European Union v. Nadiany Bamba, ECLI:EU:C:2012:718.

34 Case C-200/13, Council v. Bank Saderat Iran, ECLI:EU:C:2016:284X.

35 Case T-290/17, Edward Stavytskyi vs. Council, ECLI:EU:T:2019:37.

36 Case C - 134/19 P, Bank Refah Kargaran vs. Council, ECLI:EU:C:2020:793.

37 Case T - 348/14, Olexandr Yanukovych vs. Council, ECLI:EU:T:2016:508, para. 80.

38 Case C-280/12, Council v. Fulmen and Fereydoun Mahmoudian, ECLI:EU:C:2013:775, para 64. 
о рестриктивним мерама чињенично утемељена, те да поткрепљујуће информације у конкретном случају имају неспорну доказну вредност ${ }^{39}$.

Инсистирање судова на процесним критеријумима усмерено је ка реализацији два међусобно неодвојива циља: заштити основних принципа, начела и вредности правног поретка организације, попут владавине права, правне сигурности или принципа пропорционалности, с једне стране, али и заштити права лица која су рестриктивним мерама погођена, с друге, при чему је Суд управо овај други контекст настојао додатно искористити за јачање своје позиције у оквиру ЗСБП.

\section{3. Рестриктивне мере и заштита људских права}

Протеклих година развила се обимна судска пракса у чијем средишту је, уз идентификацију процесних критеријума, заштита права субјеката погођених санкционим мерама, а поготово њиховог права на одбрану и ефикасну судску заштиту ${ }^{40}$. Право на одбрану, између осталог, укључује право да се буде саслушан (audi alteram partem) и право увида у доказе на којима се темељи рестриктивна мера, док право на ефикасну судску заштиту укључује и ваљано образложење рестриктивне мере у односу на циљеве и вредности Уније, а које подлеже преиспитивању од стране судова ${ }^{41}$. Судови су углавном настојали обезбедити равнотежу између заштите људских права како их гарантује право организације, с једне стране, те ефикасности рестриктивних мера у контексту реализације спољнополитичких циљева Уније, с друге (Bosse Plattiere, 2017). У случају Kiselev, на пример, у којем је било речи о слободи изражавања из члана 11 Повеље о основним правима, Општи суд је истакао да ово право није апсолутно, те да може бити ограничено у сврху окончања „руске дестабилизације Украјине“, посебно уколико деловање лица у питању представља политичку пропаганду и уколико су ограничења нужна и пропорционална циљу који се жели остварити и уколико производе одвраћајућа дејства pro futuro ${ }^{42}$. Односно, судови Уније су ограничење индивидуалних права применом рестриктивних мера смештали у познати

39 Погледати и: Joined Cases C-584/10 P, C-593/10 P \& C-595/10 P, Commission v. Kadi (Kadi II), EU:C:2013:518, para. 124.

40 У складу са члановима 41 и 47 Повеље Европске уније о основним правима која, у складу са чланом 6.1 УЕУ, ужива „једнаку правну вредност“ као и уговори.

41 Погледати: Poli, S. (2018). Effective Judicial Protection and Its limits in the case law concerning individual restrictive measures in the European Union, in Neframi, E., Gatti, M. (eds.). (2018). Constitutional Issues of EU External Relations Law, Luxembourg Legal Studies, 16, Baden-Baden: Nomos, p. 287-305.

42 Case T - 262/15, Kiselev v. Council, ECLI:EU:T:2017:392, paras. 76, 116-119. 
контекст из члана 52.1 Повеље о основним правима ${ }^{43}$, али и признате судске праксе ${ }^{44}$, а који подразумева три основна момента: почивање мере на одговарајућој правној основи, повезаност ограничења са циљем Уније који се настоји остварити, те неопходност и пропорционалност ограничења у односу на дати циљ, док само „језгро“ гарантованог права мора остати нетакнуто. Руководећи се наведеним, Судје у случају Rotenberg инсистирао на „заштитној функцији“ рестриктивних мера, како у односу на права и словоде других субјеката, тако и у односу на циљеве Уније $\mathrm{y}^{45}$, док је у бројним „руским“ и „украјинским“ случајевима, који последњих година преовлађују, присутно „апотекарско“ процењивање домашаја рестриктивних мера у контексту очувања неокрњености „језгра“ права индивидуалног субјекта на којег се мера односи. У руској и украјинској групи случајева доминирају не само захтеви за поништај одлуке Савета због кршења процесних критерија, већ и захтеви за надокнаду штете коју је лице претрпело услед примене оспорених мера. Када је реч о Руској Федерацији, ови поступци су кулминирали након анексије Крима ${ }^{46}$, а као мете санкција, које су временом обнављане и прошириване ${ }^{47}$, односно као стране у каснијим поступцима за њихов поништај, појавила су се различита лица блиска Кремљу, руске компаније у области енергетике ${ }^{48}$, грађевине ${ }^{49}$,

43 Члан 52.1 Повеље гласи: „Свако ограничење права и слобода признатих овом повељом мора бити предвиђено законом и поштовати суштину тих права и слобода. Таква ограничења, под условом поштивања начела пропорционалности, могу бити допуштена само уколико су неопходна и уколико истински задовољавају циљеве од општег интереса које признаје Унија или потребу заштите права и слобода других“. 44 Погледати: Case T - 256/11, Ahmed Abdelaziz Ezz and Others v Council, ECLI:EU:T:2014:93; Case T - 202/12, Bouchra Al Assad v Council, ECLI:EU:T:2014:113.

45 Case T - 720/14, Rotenberg v. Council, ECLI:EU:T:2016:689, para. 167.

46 Council Decision 2014/145/CFSP and Council Regulation 269/2014 of 17 March 2014 concerning restrictive measures in respect of actions undermining or threatening the territorial integrity, sovereignty and independence of Ukraine, OJ L/78, 17. 3. 2014.

47 Погледати: Council Decision (CFSP) 2020/907 of 29 June 2020 amending Decision 2014/512/CFSP concerning restrictive measures in view of Russia's actions destabilizing the situation in Ukraine, OJ. L/207, 30. 6. 2020.

48 Case T - 735/14 и T - 799/14, Gazprom Neft PAO v. Council, ECLI:EU:T:2018:548; Case C - 72/15, PJSC Rosneft Oil Company v. Her Majesty's Treasury, ECLI:EU:C:2017:236; Case T 715/14, PAO Rosneft Oil Company and others v. Council, ECLI:EU:T:2018:544; Case C-732/18 P, PAO Rosneft Oil Company and others vs. Council, ECLI:EU:C:2020:727.

49 Case T - 720/14, Rotenberg v. Council, ECLI:EU:T:2016:689. 
финансија ${ }^{50}$, одбрамбене индустрије ${ }^{51}$, те руски медији због наводног дестабилизирајућег пропагандног деловања ${ }^{52}$. Украјински случајеви били су нешто специфичнији, јер се углавном радило о лицима која су већ била предмет националних поступака због наводног финансијског криминала, те су мере Уније $\mathrm{y}^{53}$ имале за циљ да подрже нове украјинске власти у њиховим напорима. При томе, политичка димензија у примени рестрикција је незаобилазна, јер је углавном била реч о припадницима претходног режима, људима блиским Кремљу ${ }^{54}$ и члановима њихове породице ${ }^{55}$, те компанијама „под контролом“ Москве ${ }^{56}$. У оквиру украјинских случајева, судови су углавном поништавали одлуке Савета због непоштивања другог процесног критерија (детаљно образложење),

50 Case T - 732/14, Sberbank of Russia OAO v. Council, ECLI:EU:T:2018:541; Case T 734/14, VTB Bank PAO v. Council, ECLI:EU:T:2018:542; Case C - 729/18, VTB Bank PAO v. Council, C-729/18 P, ECLI:EU:C:2020:499; Case T - 731/18, Vnesheconombank v. Council, ECLI:EU:T:2018:543; Case C - 731/18 P, Vnesheconombank v. Council, ECLI:EU:C:2020:500.

51 Case T - 525/15, Almaz-Antey v. Council, ECLI:EU:T:2017:25; Case T - 515/15, AlmazAntey v. Council, ECLI:EU:T:2018:545.

52 Case C - 262/15, Kiselev v. Council, ECLI:EU:T:2017:392.

53 Council Decision 2014/119/CFSP of 5 March 2014 concerning restrictive measures directed against certain persons, entities and bodies in view of the situation in Ukraine, $0 \mathrm{~J}$ L/66, 6.3.2014; Council Regulation (EU) 208/2014 of 5 March 2014 concerning restrictive measures directed against certain persons, entities and bodies in view of the situation in Ukraine, OJ L/66, 6.03.2014; Council Decision (CFSP) 2020/399 of 13 March 2020 amending Decision 2014/145/CFSP, OJ L/78.

54 Case T - 346/14, Viktor Yanukovych v. Council, ECLI:EU:T:2016:497; Case C - 598/16, Viktor Yanukovych v. Council, C-598/16 P, ECLI:EU:C:2017:786; Case T - 331/14, Mykola Azarov v. Council, ECLI:EU:T:2016:49; Case T - 215/15, Mykola Azarov v. Council, ECLI:EU:T:2017:479; Case T - 434/14, Arbuzov v. Council, ECLI:EU:T:2016:46; Case T - 221/15, Arbuzov v. Council, ECLI:EU:T:2017:478; Case T - 290/17, Stavy tskyi v. Council, ECLI:EU:T:2019:37; Case T - 290/14, Portnov v. Council, ECLI:EU:T:2015:806; Case T - 340/15, Klyuyev v. Council, ECLI:EU:T:2016:496; Case T - 305/18, Klyuyev v. Council, ECLI:EU:T:2019:506; Case T - 291/19, Victor Pshonka v. Council, ECLI:EU:T:2020:448; Case T - 269/20, Victor Pshonka v. Council, ECLI:EU:T:2021:419; Case T - 286/19, Mykola Azarov v. Council, ECLI:EU:T:2020:611; Case T - 258/20, Oleksandr Viktorovych Klymenko v Council, ECLI:EU:T:2021:52. Тренутно, у току је и поступак у случају T - 291/20, Victor Yanukovych vs. Council.

55 На пример: Case T - 332/14, Oleksii Azarov v. Council, ECLI:EU:T:2016:48; Case T - 348/14, Oleksandr Yanukovych v. Council, ECLI:EU:T:2016:508; Case T - 292/19, Artem Pshonka v. Council, ECLI:EU:T:2020:449; Case T - 268/20, Artem Pshonka v. Council, ECLI:EU:T:2021:418; Case T - 298/19, Sergej Arbuzov v. Council, ECLI:EU:T:2020:445; Case T - 267/20, Sergej Arbuzov v. Council, ECLI:EU:T:2021:417. У току је, на пример, и поступак у случају T 292/20, Oleksandr Yanukovych v. Council.

56 На пример: Case T - 739/14, PSC Prominvestbank v. Council, ECLI:EU:T:2018:547. 
а случајеви $\operatorname{Arbuzov}^{57}$ и Yanukovych ${ }^{58}$ указују да је проблем био у томе што се Савет углавном ослањао на податке из писама украјинског Врховног тужиоца, за које су судови Уније сматрали да нису довољно прецизни при утврђивању индивидуалне одговорности, као и да се посредством њих не доказује постојање опасности од деловања конкретног лица по владавину права у Украјини (Challet, 2020: 5). Судови су били мање склони поништити одлуке Савета у случајевима из „руске групе“, а један од ретких изузетака представља поменути случај Rotenberg, који се тицао рестриктивних мера против лица које је било ангажовано на изградњи моста којим се Крим повезује са руском територијом. Општи суд је поништио акт Савета из разлога што овај, без обзира на објективну везу лица са руководством Русије, није непобитно показао да је оно приликом закључења уговора било упознато са намерама руских власти, које су обзнањене накнадно, да се мост гради, а поготово да је могло утицати на одлуку Москве по овом питању ${ }^{59}$.

По питању права на накнаду штете претрпљене применом илегалних рестриктивних мера, у складу са принципом вануговорне одговорности из члана 340 УФЕУ, Унија је дужна надокнадити штету коју њене институције или службеници проузрокују при вршењу својих дужности. Суд правде временом је идентификовао три услова који морају бити испуњени како би захтев за накнадом штете био ефективан - да је причињена штета стварна, да постоји објективна веза између деловања организације и настале штете, те да је штета проузрокована озбиљним нарушавањем права организације (Тучић, 2015: 190-199). Но, судови Уније су све до случаја Safa $\mathrm{Nicu}^{60}$ избегавали да донесу одлуку у овом правцу, образлажући то неиспуњеношћу бар једног од наведених услова.У овом случају, Општи суд је констатовао да Савет није понудио поткрепљујуће доказе да компанија помаже развој иранског нуклеарног програма те је, самим тим, противна праву Уније. Потом је констатовао и да су испуњена сва три услова за накнаду штете, међутим, уместо тражена 2 милиона ${ }^{61}$, Суд је утврдио обавезу Уније да надокнади штету у износу од само 50.000 евра, jep Safa Nicu наводно свој одштетни захтев није поткрепила одговарајућим доказима о висини претрпљене штете ${ }^{62}$. Покренут је апелациони поступак пред Судом правде, у којем је компанија тражила поништај одлуке Општег суда

57 Case T - 434/14, Arbuzov v. Council, ECLI:EU:T:2016:46, para. 39.

58 Case T - 348/14, Oleksandr Yanukovych v. Council, ECLI:EU:T:2016:508.

59 Case T - 720/14, Rotenberg v. Council, ECLI:EU:T:2016:689, paras. 84-91.

60 Case T-384/11, Safa Nicu Sepahan Co. v Council, ECLI:EU:T:2014:986.

61 ibidem, para. 78.

62 ibidem, para. 93-149. 
о висини накнаде, док је Савет сматрао да Safa Nicu уопште нема право на накнаду ${ }^{63}$. Суд је, пратећи ставове општег правобраниоца ${ }^{64}$, одбацио аргументе и компаније и Савета, те подржао првобитну одлуку Општег суда. Од висине одштетног захтева значајније је то да су судови Уније коначно јасно истакли да примена индивидуалних санкција за које се испостави да су противправне дефинитивно повлачи за собом одговорност Уније за штету која је индивидуалном субјекту причињена (Pursiainen, 2017: 16).

Веома значајан случај по питању права на накнаду штете, али и позиције Суда правде у оквиру ЗСБП, био је Bank Refah Kargaran из 2020. године ${ }^{65}$, у којем се поставило питање надлежности Суда да разматра одштетни захтев који се не односи само на рестриктивне мере донете на основу члана 215.2 УФЕУ, већ и на одлуке Савета у оквиру ЗСБП усвојене на основу члана 29 УЕУ. Након што се Општи суд ${ }^{66}$ претходно прогласио ненадлежним, указујући на ограниченост уговорних решења којима се утврђује надлежност Суда правде у оквиру ЗСБП искључиво на члан 40 УЕУ, односно 275 УФЕУ, покренут је апелациони поступак пред Судом правде, који је заузео другачији став. По Суду, начело ефикасне судске заштите не би било потпуно уколико му не би било омогућено да доноси одлуке о накнади штете која је проузрокована рестриктивним мерама у оквиру ЗСБП 67 , а свој став Суд је градио на неколико елемената: дерогацији његових општих овлаштења из члана 19 УЕУ у оквиру ЗСБП ${ }^{68}$; истицању права на ефикасан правни лек сваког индивидуалног субјекта чија су права нарушена, у складу са чланом 19 Повеље, али и начелом владавине права на којем Унија почива ${ }^{69}$; тези да, како свако лице располаже правом на накнаду штете која му је причињена мерама донетим на основу члана 215 УФЕУ, принцип кохерентности система правних лекова у праву Уније налаже да идентичним правом лица располажу и када је реч о одлукама Савета донетим по члану 29 УЕУ0. Стога, Суд располаже надлежношћу да одлучује о накнади штете коју је Унија проузроковала спроводећи

63 Case C - 45/15 P, Safa Nicu Sepahan Co.v Council of the European Union, ECLI:EU:C:2017:402.

64 ibidem, Opinion of the Advocate General Mr. Mangozzi, Delivered on 8 September 2016, ECLI:EU:C:2016:658.

65 C - 134/19, Bank Refah Kargaran v Council, ECLI:EU:C:2020:793.

66 Case T - 552/15, Bank Refah Kargaran v Council, ECLI:EU:T:2018:897.

67 C - 134/19, Bank Refah Kargaran v Council, ECLI:EU:C:2020:793, para. 43.

68 ibidem, para. 32 .

69 ibidem, para. 35-36.

70 ibidem, para. 39 . 
своја овлаштења у области ЗСБП ${ }^{71}$. Очигледно, Суд правде је, под плаштом заштите начела ефикасне судске заштите и владавине права, настојао додатно ојачати своје компетенције у области ЗСБП (Verellen, 2021: 1724). Или, Суд се „без јасног реда ослонио на неколико фрагментираних аргумената, које није чак ни повезао у аргументовану целину, те устврдио своју надлежност по наведеном питању, иако је правна основа за тако нешто остала нејасна" (Bartoloni, 2020: 1364). Без обзира, након случаја Rosneft $^{72}$ и подвођења одлука Савета о рестриктивним мерама под претходни поступак, у случају Bank Refah Kargaran десила се следећа, како би рекли Крејг и Де Бурка, "groundbreaking judgement” у контексту јачања позиције Суда правде у оквиру ЗСБП (Craig and de Burca, 2011: 7).

\section{3. Закључак}

Аутономне рестриктивне мере против правних и физичких лица и других недржавних ентитета представљају веома битан и све учесталији инструмент подршке општим интересима и циљевима Уније у спољнополитичком контексту. Након дугогодишњег лутања и непознаница, Уговором из Лисабона омогућена је експлицитна правна основа за њихову примену, али и предвиђена ограничена надлежност Суда правде у оквиру ЗСБП, укључујући и надзор над легалношћу рестриктивних мера које доноси Савет. Но, и овако ограничена надлежност судова Уније у оквиру ЗСБП послужила је као основа за релативно интензиван судски активизам, и то на неколико нивоа.

Први ниво подразумевао би јачање позиције Суда правде у оквиру ЗСБП, при чему су, до сада, у овом контексту учињена два корака. Први је подразумевао подвођење одлука Савета о рестриктивним мерама под поступак о претходном питању, чиме се не само додатно учврстио канал комуникације између Суда и његових националних партнера, већ и отворио простор за интензивније јуриспрудентно обликовање даљег развоја овог веома осетљивог сегмента права европске организације. Други корак подразумевао је проширење надлежности Суда и у односу на одлуке Савета у оквиру ЗСБП донете на основу члана 29 УЕУ, на основу прилично уопштене аргументације из случаја Bank Refah Kargaran, која је изазвала доста „буре“ на теоријској равни.

71 Сличан став, али другачије аргументован, изнео је и општи правобранилац Хоган. Погледати: Opinion of AG Hogan delivered on 28 May 2020, case C-134/19 P, Bank Refah Kargaran v. Council, ECLI:EU:C:2020:396.

72 Case C-72/15, PJSC Rosneft Oil Company v. Her Majesty's Treasury, ECLI:EU:C:2017:236. 
Битан ниво деловања судова Уније односио се на идентификацију кључних процесних критеријума које одлуке Савета о рестриктивним мерама против индивидуалних субјеката морају испунити. Функционални значај ових критеријума, уз заштиту неких од основних вредности, принципа и начела Уније као „заједнице утемељене на праву“73, садржан је у интенцији Суда да се верификује као један од кључних европских правосудних ауторитета по питању заштите људских права и слобода. Један од кључних изазова судова Уније у досадашњем периоду управо се манифестовао у потреби обезбеђења одговарајуће равнотеже између ефикасности рестриктивних мера као инструмената ЗСБП, с једне, те заштите базичних садржинских елемената Уније као заједнице темељене на праву, укључујући и заштиту људских права и слобода како је предвиђена правом европске организације, с друге. Иако су у великој мери до сада у томе успевали, компарација неких од досадашњих „руских“ и „украјинских“ случајева указује да су у одређеним ситуацијама судови Уније предност ипак давали њеним спољнополитичким интересима и циљевима.

Без обзира што су поштовали његова овлаштења при идентификацији „мета“ рестриктивних мера, судови Уније су инсистирањем на процесним критеријумима вршили перманентан притисак на Савет и тиме, између осталог, утицали на побољшање квалитета ове врсте аката (Chachko, 2019). Не мањег значаја је и чињеница да су судови досадашњом праксом, иако постоје мишљења да су одређене прилике за значајнији искорак у том правцу пропуштене ${ }^{74}$, значајно утицали на јуриспрудентну хомогенизацију, односно чвршће повезивање ЗСБП са осталим политикама и осталим сегментима правног система Уније. Процеси у овом контексту нису окончани, те се у наступајућем периоду такође могу очекивати интересантни обрти у режији Суда правде.

73 Конструкцију „заједница темељена на праву“ први је употребио први председник Европске комисије Валтер Холштајн 1962. године, да би се она потом чврсто етаблирала и у јуриспруденцији Суда правде. Погледати: C - 294/83, Parti écologiste „Les Verts“ v. European Parliament, ECR I - 1339.

74 Погледати: Koutrakos, P. (2018). Judicial Review in the EU's Common Foreign and Security Policy. International and Comparative Law Quarterly, 67, DOI: 10.1017/S0020589317000380, p. 1-35. 


\section{Литература и извори}

Bartoloni, M. E. (2019). „Restrictive Measures“ under art. 215 TFEU: towards unitary legal regime? Brief reflections of Bank Refah Judgement. European Papers Insight. 5(3). DOI: 10.15166/2499-8249/442. p. 1359-1369.

Van Elsuwege, P. (2011). The Adoption "Targeted Sanctions" and the Potential for Interinstitutional Litigation After Lisbon. Journal of Contemporary European Research, 7 (4), p. 488-499.

Verellen, T. (2021). In the name of rule of law? CJEU further extends jurisdiction in CFSP (Bank Refah Kargaran). European Papers Insight. 6(1), DOI: 10.15166/24998249/447, p. 17-24.

Chachko, E. (2019). Foreign Affairs in Court: Lessons from CJEU Targeted Sanctions Jurisprudence. The Yale Journal of International Law. 44(1). p. 1-51.

Challet, C. (2020). Reflections on Judicial Review of EU Sanctions Following the Crisis in Ukraine by the Court of Justice of the European Union. Research Papers in Law, 4/20, European Legal Studies, College of Europe, Brugge.

Craig, P. \& Burca, de G. (2011). EU Law - Texts, Cases and Materials, Fifth edition, Oxford: Oxford University Press.

Koutrakos, P. (2018). Judicial Review in the EU'S Common Foreign and Security Policy. International and Comparative Law Quarterly, 67, DOI: 10.1017/ S0020589317000380, p. 1-35.

Poli, S. (2018), Effective Judicial Protection and Its limits in the case law concerning individual restrictive measures in the European Union, in Neframi, E., Gatti, M. (eds.) (2018), Constitutional Issues of EU External Relations Law, Luxembourg Legal Studies, 16, Baden-Baden: Nomos, p. 287-305.

Pursiainen, A. (2017). Targeted EU Sanctions and Fundamental Rights. Solid Plan Consulting. Retrieved on 12 July 2021 from https://um.fi/ documents/35732/48132/eu_targeted_sanctions_and_fundamental_ rights/14ce3228-19c3-a1ca-e66f-192cad8be8de?t=1525645980751.

Тучић, Б. (2015). Суверенитет, јуриспруденција и уставни плурализам: оглед о правном поретку Европске уније. Бања Лука: ЈУ Народна и универзитетска библиотека Републике Српске.

Тучић, Б. (2020). Основи политике интеграције и сарадње у области унутрашњих послова и правосуђау Европској унији: правни и институционални оквир „Простора слободе, безбједности и правде“. Бања Лука: Факултет безбједносних наука Универзитета у Бањој Луци. 
Уговор о Еуропској унији и Уговор о функционирању Еуропске уније прочишћене верзије, ОJ C 202, 2016, p. 1 - 388. Преузето 3. јула 2021. ca https:// eur-lex.europa.eu/legal-content/HR/TXT/?uri=CELEX\%3A12016ME\%2FTXT.

Акти институција Европске уније

Common Position of 19 March 1998 on restrictive measures against the Federal Republic of Yugoslavia, OJ 1998 L 95/1.

Common Position of 7 May 1998 concerning the freezing of funds held abroad by the Federal Republic of Yugoslavia (FRY) and Serbian Governments, OJ 1998 L 143/1.

Council Common Position 1999/727 of 15 November 1999 concerning restrictive measures against the Taliban OJ L 294.

Council Common Position 2001/154 of 26 February 2001 concerning additional restrictive measures against the Taliban and amending Common Position 96/746/CFSP, OJ L 57, 27. 2. 2001.

Council Common Position of 27 December 2001 on the application of specific measures to combat terrorism, OJ L 344, 28. 12. 2001.

Council Common Position of 27 May 2002 concerning restrictive measures against Usama bin Laden, members of the Al-Qaida organization and the Taliban and other individuals, groups, undertakings and entities associated with them and repealing Common Positions 96/746/CFSP, 1999/727/CFSP, 2001/154/CFSP and 2001/771/CFSP, OJ L 139, 29. 5. 2002.

Council Decision 2014/119/CFSP of 5 March 2014 concerning restrictive measures directed against certain persons, entities and bodies in view of the situation in Ukraine, OJ L/66, 6. 3. 2014.

Council Decision CFSP 2014/145 of 17 March 2014 concerning restrictive measures in respect of actions undermining or threatening the territorial integrity, sovereignty and independence of Ukraine, OJ L 78/16, 17. 3. 2014.

Council Decision CFSP 2016/1711 of 27 September 2016 amending Common Position 2001/931/CFSP on the application of specific measures to combat terrorism, L 2591, 27. 9. 2016.

Council Decision (CFSP) 2017/2073 of 13 November 2017 amending Common Position 2001/931/CFSP on the application of specific measures to combat terrorism, L 295, 14. 11. 2017. 
Council Decision (CFSP) 2020/399 of 13 March 2020 amending Decision 2014/145/CFSP, OJ L/78, 13. 3. 2020.

Council Decision (CFSP) 2020/907 of 29 June 2020 amending Decision 2014/512/ CFSP concerning restrictive measures in view of Russia's actions destabilizing the situation in Ukraine, OJ. L/207, 30. 6. 2020.

Council Regulation (EC) No 337/2000 of 14 February 2000 concerning a flight ban and a freeze of funds and other financial resources in respect of the Taliban of Afghanistan, OJ L 43/20, 16. 2. 2020.

Council Regulation (EC) No 2488/2000 of 10 November 2000 maintaining a freeze of funds in relation to Mr. Milosevic and those persons associated with him and repealing Regulations (EC) No. 1294/1999 and 607/2000 and Article 2 of Regulation (EC) No 926/98, OJ 2000 L 287/19, 14. 11. 2000.

Council Regulation (EC) No 467/2001 of 6 March 2001 prohibiting the export of certain goods and services to Afghanistan, strengthening the flight ban and extending the freeze of funds and other financial resources in respect of the Taliban of Afghanistan, and repealing Regulation (EC) No 337/2000, OJ $2001 \mathrm{~L}$ 67/1, 9. 3. 2001.

Council Regulation (EC) No 881/2002 of 27 May 2002 imposing certain specific restrictive measures directed against certain persons and entities associated with Usama bin Laden, the Al-Qaida network and the Taliban, and repealing Council Regulation (EC) No 467/2001 prohibiting the export of certain goods and services to Afghanistan, strengthening the flight ban and extending the freeze of funds and other financial resources in respect of the Taliban of Afghanistan, OJ L 139, 29. 5. 2002.

Council Regulation (EU) No 1286/2009 of 22 December 2009 amending Regulation (EC) No 881/2002 imposing certain specific restrictive measures directed against certain persons and entities associated with Osama bin Laden, the AlQaida network and the Taliban, O.J. 2009, L 346/42.

Council Regulation (EU) 208/2014 of 5 March 2014 concerning restrictive measures directed against certain persons, entities and bodies in view of the situation in Ukraine, 0J L/66, 6. 3. 2014.

Council Regulation 269/2014 of 17 March 2014 concerning restrictive measures in respect of actions undermining or threatening the territorial integrity, sovereignty and independence of Ukraine, 0J L/78, 17. 3. 2014.

European Parliament Committee on Legal Affairs Opinion on the legal basis of the proposal for a Council Regulation amending Regulation (EC) No 881/2002 imposing certain specific restrictive measures directed against certain persons 
and entities associated with Osama bin Laden, the Al-Qaida network and the Taliban, JURI_AL(2009) 430917, 4 December 2009.

Судска пракса Суда правде ЕУ и Општег суда

C - 294/83, Parti écologiste “Les Verts” v European Parliament, ECR I - 1339.

Case T-362/04, Leonid Minin v. Commission, 2007, ECR II-2003.

Joined Cases C-402/05 P and C-415/05 P, Kadi and Al Barakaat, 2008, ECR I-6351.

Joined Cases T-246/08 and T-332/08, Melli Bank plc v. Council, 2009, ECR II-2629.

Case C - 130/10, European Parliament v. Council, ECLI:EU:C:2012:472.

Joined Cases C-584/10 P, C-593/10 P \& C-595/10 P, Commission v. Kadi (Kadi II), EU:C:2013:518.

Case T - 256/11, Ahmed Abdelaziz Ezz and Others v Council, ECLI:EU:T:2014:93.

Case T-384/11, Safa Nicu Sepahan Co. v Council, ECLI:EU:T:2014:986.

Case C-417/11, Council of the European Union v. Nadiany Bamba, ECLI:EU:C:2012:718.

Case C-658/11, EP v Council (Mauritius), ECLI:EU:C:2014:2025.

Case T - 202/12, Bouchra Al Assad v Council, ECLI:EU:T:2014:113.

CaseC-280/12,CouncilvFulmenandFereydoun Mahmoudian,ECLI:EU:C:2013:775.

Case C-200/13, Council v Bank Saderat Iran, ECLI:EU:C:2016:284X.

Case C-439/13P, Elitaliana, ECLI:EU:C:2015:753.

Case C-630/13, Issam Anbouba v Council, ECLI:EU:C:2015:247.

Case T - 290/14, Portnov v. Council, ECLI:EU:T:2015:806.

Case T - 331/14, Mykola Azarov v. Council, ECLI:EU:T:2016:49.

Case T - 332/14, Oleksii Azarov v. Council, ECLI:EU:T:2016:48.

Case T - 346/14, Viktor Yanukovych v. Council, ECLI:EU:T:2016:497.

Case T - 348/14, Olexandr Yanukovych vs. Council, ECLI:EU:T:2016:508.

Case T - 434/14, Arbuzov v. Council, ECLI:EU:T:2016:46.

Case C-455/14P H v Council, ECLI:EU:C:2016:569.

Case $\mathrm{T}$ - 715/14, PAO Rosneft Oil Company and others v. Council, ECLI:EU:T:2018:544. 
Case T - 720/14, Rotenberg v. Council, ECLI:EU:T:2016:689.

Case T - 732/14, Sberbank of Russia OAO v. Council, ECLI:EU:T:2018:541.

Case T - 734/14, VTB Bank PAO v. Council, ECLI:EU:T:2018:542.

Joined cases T - 735/14 and T - 799/14, Gazprom Neft PAO v. Council, ECLI:EU:T:2018:548.

Case T - 739/14, PSC Prominvestbank v. Council, ECLI:EU:T:2018:547.

Case C - 45/15 P, Safa Nicu Sepahan Co. v Council of the European Union, ECLI:EU:C:2017:402.

Case C - 45/15 P, Safa Nicu Sepahan Co. v Council of the European Union, Opinion of the Advocate General Mr. Mangozzi, Delivered on 8 September 2016, ECLI:EU:C:2016:658

Case C - 72/15, PJSC Rosneft Oil Company v. Her Majesty's Treasury, ECLI:EU:C:2017:236.

Case C-72/15, Rosneft, Opinion of Advocate General Wathelet delivered on 31 May 2016, ECLI:EU:C:2016:381.

Case T - 221/15, Arbuzov v. Council, ECLI:EU:T:2017:478.

Case T - 215/15, Mykola Azarov v. Council, ECLI:EU:T:2017:479.

Case T - 262/15, Kiselev v. Council, ECLI:EU:T:2017:392.

Case T - 340/15, Klyuyev v. Council, ECLI:EU:T:2016:496.

Case T - 515/15, Almaz-Antey v. Council, ECLI:EU:T:2018:545.

Case T - 525/15, Almaz-Antey v. Council, ECLI:EU:T:2017:25.

Case T - 552/15, Bank Refah Kargaran v Council, ECLI:EU:T:2018:897.

Cases C - 598/16, Viktor Yanukovych v. Council, C-598/16 P, ECLI:EU:C:2017:786.

Case T-290/17, Edward Stavytskyi vs. Council, ECLI:EU:T:2019:37.

Case T - 305/18, Klyuyev v. Council, ECLI:EU:T:2019:506.

Case C - 729/18, VTB Bank PAO v. Council, C-729/18 P, ECLI:EU:C:2020:499.

Case T - 731/18, Vnesheconombank v. Council, ECLI:EU:T:2018:543.

Case C - 731/18 P, Vnesheconombank v. Council, ECLI:EU:C:2020:500.

Case C-732/18 P, PAO Rosneft Oil Company and others vs. Council, ECLI:EU:C:2020:727. 
Case C - 134/19 P, Bank Refah Kargaran vs. Council, ECLI:EU:C:2020:793.

Case C-134/19 P, Bank Refah Kargaran v. Council, Opinion of AG Hogan delivered on 28 May 2020, ECLI:EU:C:2020:396.

Case T - 286/19, Mykola Azarov v. Council, ECLI:EU:T:2020:611.

Case T - 291/19, Victor Pshonka v. Council, ECLI:EU:T:2020:448.

Case T - 292/19, Artem Pshonka v. Council, ECLI:EU:T:2020:449.

Case T - 298/19, Sergej Arbuzov v. Council, ECLI:EU:T:2020:445.

Case T - 258/20, Oleksandr Viktorovych Klymenko v Council, ECLI:EU:T:2021:52.

Case T - 267/20, Sergej Arbuzov v. Council, ECLI:EU:T:2021:417.

Case T - 268/20, Artem Pshonka v. Council, ECLI:EU:T:2021:418.

Case T - 269/20, Victor Pshonka v. Council, ECLI:EU:T:2021:419. 
Boris Tučić, PhD,

Assistant Professor,

Faculty of Security Science, University of Banja Luka

\title{
THE COURT OF JUSTICE OF THE EUROPEAN UNION AND THE AUTONOMOUS RESTRICTIVE MEASURES AGAINST NATURAL AND LEGAL PERSONS AND NON-STATE ENTITIES WITHIN THE EU COMMON FOREIGN AND SECURITY POLICY
}

\begin{abstract}
Summary
As a part of its specific policies, the EU creates and implements numerous restrictive measures against different subjects. In recent years, the most interesting ones, especially from the perspective of the Court of Justice of the European Union (CJEU), have been the autonomous restrictive measures against natural and legal persons and other non-state entities within the Union's Common Foreign and Security Policy (CFSP). After years of legal wandering in this regard, the Lisbon Treaty finally offered an explicit legal basis for this kind of measures, envisaging, as well, for the first time, the CJEU's jurisdiction in the field of CFSP in some cases, including the one related to reviewing the legality of decisions providing for restrictive measures against natural or legal persons adopted by the Council of the EU on the basis of Chapter 2 of Title V of the Treaty of the European Union.

In this regard, the subject matter of this paper are the activities of the EU courts related to the autonomous restrictive measures against individual subjects, analyzed at several relevant although inseparable levels. The first one considers the intention of the CJEU to "use" the situation regarding the autonomous restrictive measures in order to strengthen its position and competences within the CFSP. The second one is oriented to the efforts of the courts to secure the balance between the effectiveness of the CFSP instruments, on the one hand, and the protection of some of the major principles and values of the EU legal order, on the other hand, such as the rule of law, legal certainty, effective judicial protection or the protection of human rights as guaranteed by the EU Law in general. Thirdly, a very important step in this context has been the jurisprudential identification of the key procedural requirements that the Council's decisions providing for restrictive measures must fulfill as well (aka the designation criteria, statements of reasons criteria and supporting evidence criteria). By constantly insisting on the fulfillment of these criteria, the EU courts exerted a pressure on the Council to improve its decisions providing restrictive measures in a qualitative manner.
\end{abstract}

Recent jurisprudence, such as the Rosneft or Bank Refah Kargaran cases, shows that there is still enough space for the Court's interventions in this field, and that 
some interesting Court's decisions, related to its position within the CFSP or the general relation between the CFSP and other forms of Union's external activities, could be expected in the years to come.

Keywords: EU Common Foreign and Security Policy, autonomous restrictive measures, jurisprudence, natural and legal persons and other non-state entities, CJEU, General Court, procedural criteria, human rights. 